\title{
LETTERS OF WASHINGTON IRVING
}

\author{
EDITED BY CLARA AND RUDOLF KIRK
}

THE following letter from Washington Irving to his older brother, William Irving, is the seventh and last of the Irving manuscript letters in the Library of Rutgers University. The first six letters, written to Washington's brothers, Peter and William, and to Andrew Hicks, during his first trip abroad, were published in The Journal for December and June of 1945 and 1946.

\section{Part Three - Irving in London}

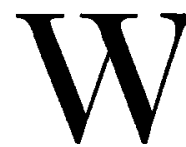

HEN Irving sailed from New York, May 19, I804, on a vessel bound for Bordeaux, he carried with him a small vellum-bound Journal in which he intended to jot down his impressions of Europe. These jottings were published by William P. Trent in I 920 under the title Mr. Irving's Notes and Journal of Travel in Europe. The first three manuscript letters in the Rutgers Library are based on these brief notes that the youthful Irving wrote in his Journal as he sat at a tavern table or on the deck of a ship. The entries, however, grew briefer as Irving travelled from Bordeaux to Italy and back to Paris, and learned to participate more fully in the interesting life around him. By the time he reached Paris, in May, I 805, he had put aside his Journal, and, instead, wrote from time to time in a small note-book which he carried with him. We are fortunate to be able to publish here a letter written from Washington to William Irving at a time when the traveller made few entries in his note-book. In this letter, the last of our series, Irving compares the character of the Englishman with that of the Frenchman, describes the latest London fashions, and reports on the plays and actors of the season.

Remembering the "gay, good-humored air" of the Parisians, Irving found the Londoners reserved, and haughty. When he discovered that his "light gray coat, white embroidered vest and colored small clothes" did not please the English, he made "a complete reformation" of his dress, thereby turning himself into a Londoner. Once settled in his lodgings, Irving began to look about him with more satisfaction. Though his letters of introduction to British 
nobility had miscarried, he still possessed those to Mrs. Johnson of the Park Theater, and to Miss De Camp of Covent Garden. At the home of the latter he met Charles Kemble, whose acting he discusses, in the last of the following letters, with the acumen of an experienced theater-goer.

But Irving's year abroad had now stretched out to almost two. "Thank heavens my ramblings are nearly at an end and in a little while I shall once more return to my friends and sink again into tranquil domestic life," he wrote to his brother. Accordingly, on January 17, 1806, he set sail for New York on the ship "Remittance," and after a voyage of 52 days, he was again with his family and friends.

\section{My Dear Brother*}

London, $\mathrm{OCT}^{\mathrm{r}} 26^{\text {th }} \mathrm{I} 805$.

You are curious perhaps to know what were my sensations on first arriving in England; I would willingly gratify you with a minute account of them if it were possible, but in such a situation my ideas $\mathcal{E}^{2}$ emotions are so confused, so various, so fugitive, that it is out of my power to analyse them.

When at Anchor opposite Gravesend I regarded the shore with a wishful eye. I longed to reach it and mingle among people whose language $\mathcal{E}^{\circ}$ manners would almost make me fancy myself at home. I reflected that I was "bone of their bone $\mathcal{E}$ flesh of their flesh" and was but entering the land of my forefathers. With such ideas you will suppose no doubt that on landing my heart expanded with the most friendly sentiments and my feelings were ready to fly out $\mathcal{E}^{\circ}$ hail each Englishman as a kinsman.-Quite the contrary-never did I enter a country with my bosom filld with such ungenerous-uncharitable sentiments. All that I had heard or read to the disadvantage of the English character seemed to rush to mind-haughtiness, illiberal prejudice, reserve, rudeness, insolence brutality, knavery were the black traits that presented themselves. I looked round me with

* To William Irving. For a comparison of this letter with entries in Irving's Notebook, see Trent, op. cit., III, 167-173. This letter from the line "Kemble appears to me to be a very studied actor" to the end is reprinted in Pierre Irving, op. cit., I, 75-77, with minor variations. We have no Journal for the London days. Irving's account book, kept during his stay in London between October and the following January, lists 29 plays which he saw. 
distrust and suspicion-my heart was completely closed up and every frank generous feeling had retired within it. I thought myself surrounded by rogues $\mathcal{E}$ swindlers and felt that I was a foreigner among people who regard all foreigners with contempt $E^{2}$ enmity.

How different is this from what I felt on arriving at Paris. It was there all confidence $\mathcal{E}^{2}$ affability-The gay, goodhumoured air of the inhabitants put me perfectly at my ease and I knew that being a stranger I had a prescriptive right to their politeness and civilities; for in France (to the honor of the nation be it spoken) the name of Stranger is sacred and entitled to all possible respect $\mathcal{E}^{3}$ attention. I even delighted in addressing the commonest people and making enquiries, and felt sure of receiving those "small sweet courtesies," that make the intercourse of man $\mathcal{E}^{2}$ man so agreeable. I had nothing to apprehend from impertinence or slight-and the argus pride, which is ever on the watch lest self consequence should be insulted, - seemed to slumber during my whole stay in paris. In London on the contrary $I$ almost feared to make the necessary enquiries about the situation of streets $\xi^{2}$ houses. I thought every one eyed me with hostility, and perceived that I was a foreigner-and I expected every moment to experience some rudeness or vulgarity. My hands were half the time in my pockets to guard them from depredations, in short I was completely on the alert. These Ideas were whimsical enough - they soon wore off and in a day or two I found I might walk the streets of London with as much confidence as those of paris. Tho I have by no means experienced the same degree of politeness, as at the latter place; yet I have not sufferd the slightest impertinence, and my pockets tho very frequently exposed, have never been plundered.

On entering London I put up at the New York Coffee house aside of the Royal Exchange. the next day however I went out with my fellow traveller $\mathrm{M}^{\mathrm{r}}$ Gorham to look for rooms. We experienced considerable difficulty in suiting ourselves either the rooms were inconvenient-or the price was too high-or the people were not sufficiently good-humoured $\mathcal{E}^{3}$ attentive. I wondered at the latter, as they made a living by letting lodgings-but on leaving one house I heard the mistress say to the servant girls "Im sure they're foreigners from their dress"; the mystery now was out-I had on a light grey coat white embroiderd vest and coloured small clothes when 
all england was in mourning ${ }^{19}$ - I determined without delay to call in the assistance of a Taylor and make a complete reformation in my dress, that article so important to be attended to in england.

At length I found lodgings to my liking. The house is kept by an old Lady dressd in black of a venerable appearance - a mighty good honest old soul. I have a parlour bed room $E$ cabinet on the ground floor-tho the furniture is not quite so modern $\mathcal{E}^{\circ}$ fashionable as some I had seen-it was so clean, well polished and together with the rooms had such a genteel, respectable comfortable appearance that I made no hesitation in deciding in favor of the old Lady. The house is admirably well situated for my views-it is in Norfolk Street (no 35)-Strand and not far from the City so that tho not subject to the bustle and confusion of the latter, I am not too far removed from the Coffee houses-exchange $\mathcal{E}^{2}$ other places of resort -While the Theatres are close at hand. The street I live in is broad clean and airy and my rooms are very light, a great advantage in this foggy climate during the gloomy months.

A stranger from the continent must be struck with the difference between the physical construction of the english and french-They are as opposite in this as in their moral characteristics. The french are generally light but well made; the idea that they are a meagre half starvd-looking race of people is a vulgar error, they have not it is true that superfluous fat that only disfigures and embarasses the human form, but their limbs are well turnd and display a union of agility $\mathcal{E}$ strength. Their complexions are sallow and their eyes black $\mathcal{E}$ lively. The English are athletic and rather inclining to corpulency their limbs heavy and ill made the joints, particularly the knees $\mathcal{F}^{2}$ ankles large - this gives them more actual strength than the french, but they have not the agility of the latter. Their countenances are full $\mathcal{E}$ ruddy-their eyes generally grey or blue the nose almost universally turnd up a little. They are a hearty, handsome, haughty looking people of a gross well fed appearance and it seems as if roast beef $\mathcal{E}^{2}$ plumb pudding were continually staring you in the face. Easy in his circumstances and well assured of his personal security, the Englishman looks around him with proud independence. The proper importance which the constitution $\mathcal{E}$ laws of England give to the indi-

${ }^{19}$ William Henry, Duke of Gloucester and Edinburgh, brother of George III, died August 25, 1805 . 
vidual has an effect on his manners $\mathcal{E} \mathcal{F}$ deportment that cannot fail but strike the observing stranger from the continent. In the shop keepers $\mathcal{E}$ tradesmen, while I have ever experienced from them the profoundest respect $\mathcal{E}$ attention, I remarked an independence of manners, a degree of self respect and personal consequence that $I$ have never before witnessed in Europe. The difference between the french $\mathcal{E}$ english women is not less striking than between the men. The french women have the advantage of form to an eminent degree. Their figures are small and exquisitely proportiond and they take pains to set them off by a lightness of drapery, not inconsistent with the mildness of their climate. The english women tho deficient in the beauties of form, have charming countenances rather of a grave cast but expressive of sentiment $\mathcal{E}$ feeling. Their figures would not be bad if they took pains to dress $\mathcal{E}$ carry themselves properly but they load on garment over garment without taste and their clothes hang about them as if hung on pegs. They have now a fashion of wearing huge tippets of bear or fox skin, which, added to an habitual stoop in the shoulders gives them the appearance of having a hunch there equal to a Dromedarys. When they walk it is a kind of hobbling uneven gait owing to their being continually crampd up in carriages or shackled with pattens. The french women are remarkable for the grace and vivacity of their movements - they can never be seen to greater advantage than on the promenade, excepting it is in the ball room. Their countenances are lively and with a pair of pretty eyes $\mathcal{E}^{3}$ good teeth (which they have very generally) a french woman can do every thing. She has an air of good humour $E$ affability that draws you to her and encourages you to be sociable. The english woman-with a countenance of the most fascinating loveliness-possesses a dignified reserve that forbids familiarity and awes you into respect. She strikes you by her beauty - the french woman wins you by a thousand little graces and amiabilities-the former is a divinity you feel inclined to admire $\mathcal{E}^{2}$ worship-the latter to laugh $\mathcal{E}$ sport with; She enchants your imagination but the former enslaves your heart.- Here am I addressing a long dessertation upon women to a sober, steady married man - its a whimsical subject enough, and you perhaps (like the wise Soloman who never judged of any thing till after he had indulged in it to satiety,) will pronounce it "all vanity $\xi$ vexation of spirit." 
Kemble is the "grand Colossis" of Tragedy in London and is considered as infallible by an english audience as the pope is by all true catholics. Yet I cannot subscribe to this opinion even tho' I should risk the damnation of the critics for such an avowal. I have seen some peices of acting from $\mathrm{M}^{\mathrm{r}}$ Kemble that from any other performer would have been termed very indifferent. But the good natured folks have got into the habit of thinking that he has some particular $E$ sterling meaning in every thing he does. When therefore in a passage that requires energy $\mathcal{E}^{\circ}$ warmth-he does not particularly exert himself-but suffers his natural coldness of style, to prevailthe audience immediately discover that he is expressing smothered grief-calm despair or dignified firmness. Kemble appears to me to be a very studied-artificial actor. His performances throughoutevince deep study and application joind to amazingly judicious conception. They are correct $\mathcal{E}^{2}$ highly finished paintings but much labored. Thus therefore, when witnessing the exertions of his powers - tho my head is satisfied and even astonished-yet my heart is seldom affected. I am not led away to forget that it is Kemble the actor, not Othello the Moor. Once I must own however I was completely overpowerd by his acting. It was in the part of $\mathrm{Zanga}^{20}-$ he was great throughout-but his last scene with Alonzo was truly sublime-I then, in very truth, forgot that it was a mere mimic scene before me, indeed Kemble seemed to have forgotten it himself, and for the moment to have fancied himself Zanga. When the delusion ceased I was enraptured, I was surprized at what had been my emotions-I could not have believed that Tragic representation could so far deceive $[s i c]$ the senses $\mathcal{E}$ the judgment. I felt willing to allow Kemble all the Laurels that had been awarded him. The next time I saw him however, I was less satisfied. It was in the character of Othello. Here his performance was very unequal. In many parts he was cold $\mathcal{E}^{2}$ labored-in the tender scenes he wanted mellowness, (I think him very often wanting in this quality) it was only in particular scenes that he seemed to collect all his powers and exert them with effect. His speech to the senate was lofty $E^{\circ}$ admirable-indeed in declamation he is excellent. The last time I saw him was in the part of Iaffier ${ }^{21}$ and $I$ again remarked that it was but in certain passages

${ }^{20}$ A character in Edward Young's The Revenge.

${ }^{21}$ A principal character in Otway's Venice Preserv'd. 
that he was strikingly fine-tho his correct and unceasing attention to the character was visible throughout.

Kemble treads the stage with peculiar grace $\mathcal{E}^{2}$ dignity His figure is tall $\mathcal{G}^{2}$ imposing-much such an one as Fennels. ${ }^{22}$ His countenance is noble $\mathcal{E}^{2}$ expressive-in a word he has a most majestic presence. I must not forget to observe that the Pierre ${ }^{23}$ to Kembles Iaffier was acted by $\mathrm{M}^{\mathrm{r}}$ Hargrave-and a noisy swaggering bully did he make of him-I would have given any thing to have had Cooper ${ }^{24}$ or Fennel in the character-so you see a principal character may be miserably performed even on a London stage. Kembles grand disadvantage is his voice-it wants the deep rich bass tones-and has not sufficient extent. Constant exercise has doubtless done a vast deal for it - and given it a degree of flexibility and softness which it had not naturally. Some of its tones are touching and pathetic, but when violent exclamation is necessary it is evident from the movements of his head and mouth $\mathcal{E}$ chest that he is obliged to use great exertions. This circumstance was at first a considerable draw back on the pleasure I received from his performances. I begin now to get reconciled to it and not to notice it so much which confirms me in the opinion I originally entertained that it is necessary to become in some degree accustomed to Kembles manner before you can perfectly enjoy his acting. To give you if possible a fuller idea of my general opinion of Kemble I shall only say that tho at present I decidedly give him the preference yet were Cooper to be equally studious $\mathcal{E}^{2}$ pay equal attention to his profession I would transfer it to him without hesitation. It would be a long time however before $C$. would be equally correct in his performances. Perhaps he would never be so-his style is different and with a little correction-its warmth $\mathcal{E}$ richness would perhaps make up for the want of Kembles correctness $\mathcal{E}^{2}$ precision. Actors are like painters-they seldom combine all these qualities but excel in different styles.

Cooke-is the next to Kemble in the tragic department-or rather his equal taking them in their different lines. Cookes range is rather confined-The artful designing Hypocrite is his forte and in Iago

22 James Fennell (1766-1816), American actor.

23 A character in Otway's Venice Preserv'd.

24 Thomas Abthorpe Cooper, whose acting of Shakespeare and many eighteenth century plays Irving had enjoyed for years in the theater on Park Row, New York. 


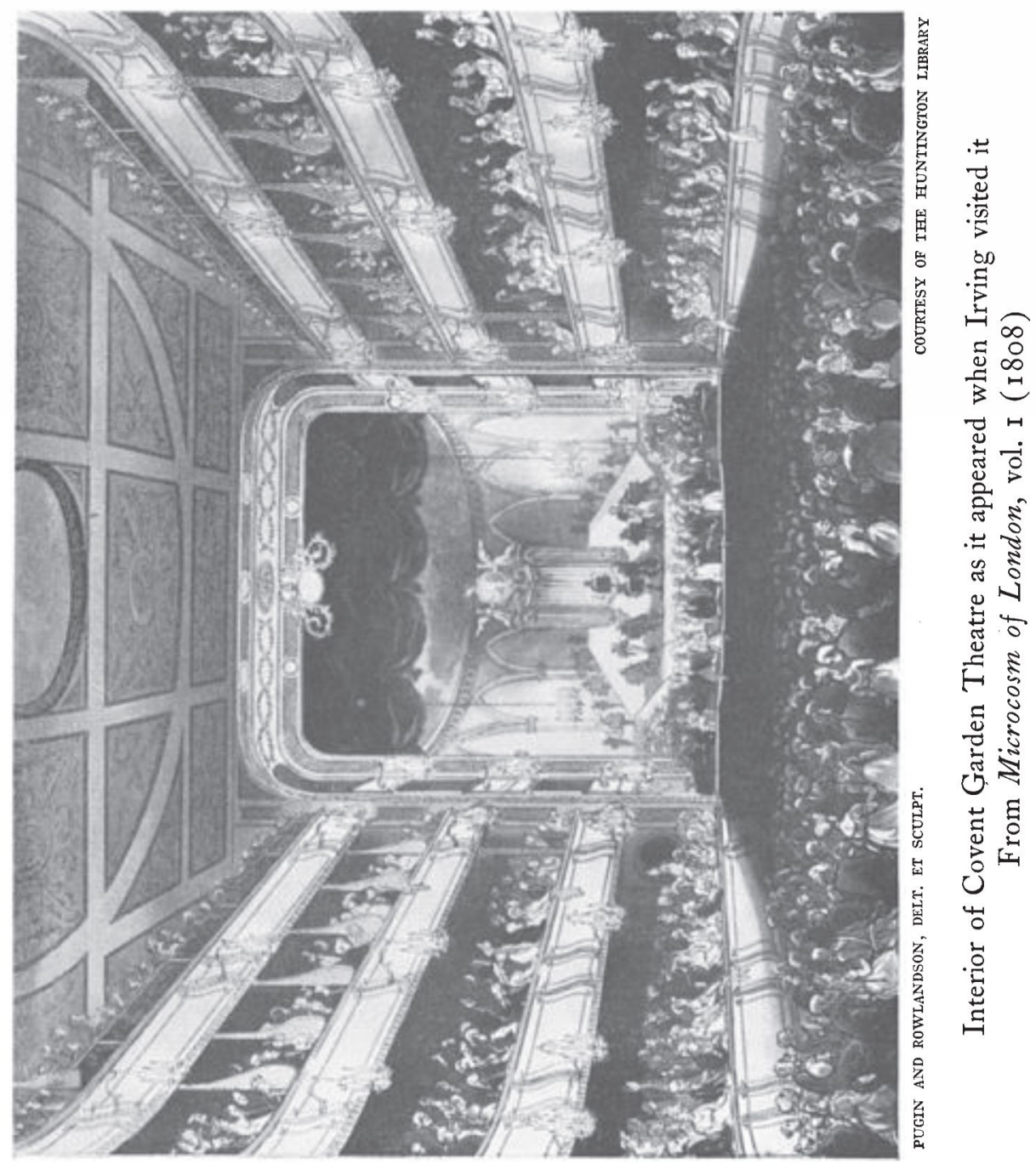


he is admirable. I never was more completely satisfied with a performance. His Richard I am told is equally good but I have not seen it. In Sir Pertinax MacSycophant ${ }^{25}$ also, he is every thing that could be desired and gives the Scotch accent with peculiar richness. Notwithstanding that he has disgusted the audience several times in consequence of his bacchanalian festivities he is a vast favorite and is always haild with the warmest applause. Indeed I am told he performs with peculiar spirit when inspired by the grape, he must at any rate be mellow on such occasion.

Were $\mathrm{I}$ to indulge with out reserve in my praises of $\mathrm{M}^{\mathrm{rs}}$ Siddons I am afraid you would think them hyperbolical. What a wonderful woman! The very first time I saw her perform I was struck with admiration. It was in the part of Calista ${ }^{26}$ - Her looks-her voice her gesture delighted me-She penetrated in a moment to my heart she froze $\mathcal{E}$ melted it by turns-a glance of her eye-a start-an exclamation thrilld thro my whole frame. The more I see her the more I admire her-I hardly breathe while she is on the stage - she works up my feelings till I am like a mere child. and yet this woman is old and has lost all elegance of figure-think then what must be her powers that she can delight $\mathcal{E}$ astonish even in the character of Calista $\mathcal{E}^{2}$ Belvidera. ${ }^{27}$ In person $\mathrm{M}^{\mathrm{rs}} \mathrm{S}$. is not unlike her sister $\mathrm{M}^{\mathrm{rs}}$ Whitlock for she has latterly rather outgrown in size the limits even of en bon point. I even think there is some similarity in their countenances tho that of $\mathrm{M}^{\mathrm{rs}} \mathrm{S}$. is infinitely superior. It is in fact the very index of her mind and in its mutable transitions may be read those nice gradations of passion that language is inadequate to express. In dignity and grace she is no ways inferior to Kemble, and they never appear to better advantage than when acting together. What $\mathbf{M}^{\mathrm{rs}}$ Siddons may have been when she had the advantages of youth and form I cannot say-but it appears to me that her performance at present leaves room to wish for nothing more-Age had planted no visible wrinkles on her brow and it is only by the practice $\mathcal{E}$ experience of years that she has been enabled to attain to her present consummate excellence.

[Here the manuscript ends.]

${ }^{25}$ A character in Charles Macklin's The Man of the World.

${ }^{26}$ The heroine of Rowe's Fair Penitent.

${ }^{27}$ The heroine of Otway's Venice Preserv'd. 